\title{
ROLE OF ABHYANGA IN JARA - A REVIEW
}

\section{Rashmi G. Dike*1, Sumit R. Patil ${ }^{2}$}

1. Assistant Professor,

2. Associate Professor and HOD,

Dept of Panchakarma, Dr. J. J. Magdum Ayurved Medical College, Jaysingpur, Maharashtra.

*Corresponding Author: Email id- dr.rashmidk7@gmail.com; Mobile Number 9970866336

\begin{abstract}
Ayurveda is a science of life which deals with preventive and curative aspects of the disease. . Jara is the natural and irreversible process of decaying and this manifested by various degenerative changes. In Vriddhavastha; Rasaraktadi Dhatu, Indriya, Bala etc.became Kshir Aging related changes are noticeable frop the $5^{\text {th }}$ decade of life; among them skin related changes are mostly noticeable. Valli, Khalli, Twakparushata, diminished vision, Nidranasha are common problems of old age persons. In benefits of Abhyanga it was stated that, it prevents from the aging process by nourishing the Dhatus. In benefits of Padabhyanga, Acharya Vagbhata stated that it helps in improving vision. During Abhyang, serotonin released which helps in Nidranasha. So Abhyanga helps in prevention of Jara.
\end{abstract}

KEYWORDS :- Jara, Abhyanga .

\section{INTRODUCTION}

Ayurveda having holiastic approach in prevention, promotion, preservation and also cure from disease. The life span of every individual has divided into 3 parts Balyavastha, Madhyamvastha, Vriddhavastha i.e. Jara, having influence of Vata. Jara is the last phase of life which describes as Swabhavaj ${ }^{l}$.Which means natural and irreversible process as well as natural disorder. Jarachikitsa is mentioned s separate branch in Asthnga Ayurveda *ontributing the treatment of Jara $^{2}$. Acharya Vagbhata quoted Abhyanga Aachareanitya as Jarahar in Dincharyaadhyaya $^{3}$.Aging is a complex and inevitable process begins before birth and continues through the entire life span. Every cell and tissue of body undergoes changes as age advances. The word Geriatric consist of two words Gerias and iatric. Gerias means to grow old whereas itric means medical treatment. In this paper role of Abhyanga geriatric is discussed as Acharya Vagbhta say that Abhyanga as Jarahar.

\section{MATERIALS AND METHODS:}

\section{Material:}

1) Literature review from Ayurvedic Classics.

2) Literature review from Modern Text. 
3) Journals and websites.

\section{Methods:}

\section{Concept of Jara}

Ayurveda calssics has given detailed description about Vaya which is based on the degenerative changes in the body. Acharya Charaka defines Vaya as state of body corresponding to the length of time that passed since birth. Further he divided Vaya in 3 parts, Balyavastha, from the age of 1 to 16 Aparipakva Dhatu and Vivardhanam Dhatu from the age of 17 to 30 years, Madhyamavastha from the age of 30 to 60 years and Vruiddhavastha from the age 70 to 100 years. There is a diminution of Dhatu and dominance of Vata $^{4}$. Acharya Sushruta classified Vaya as Balyavastha, Madhyamavastha and Vriddhavastha 5 .While Acharya Sharangadhara has narrated decade wis decline condition of body. According him Balyavastha will diminished in decade, in $2^{\text {nd }}$ decade Vriddhi, in $3^{\text {rd }}$ decade Chhavi means complexion diminished, In $4^{\text {rth }}$ decade Medha i. e. intellectual capacity of individual decreases. In $5^{\text {th }}$ decade Twak i.e. Skin losses its elasticity and Valli (wrinkles) appears. In $6^{\text {th }}$ decade Drishti diminished. In $7^{\text {th }}$ decade Shukrakhaya, And Buddhi in the $8^{\text {th }}$ decade, Karmendriya in $9^{\text {th }}$ and Manas in $10^{\text {th }}$ decade $^{6}$. The effect of Jara is clearly noticeable from the $5^{\text {th }}$ decade of life. Acharya Sushruta has mentioned Jara as Svabhavajvyadhi. After age of 70 years, Rasaraktadi Dhatus, Indriya, Bala, Virya, Utsaha become Kshina and Valli, pallitya, Khallitya, Twakparushta noticeable sign ${ }^{7}$.

\section{Skin related changes in Aging}

Skin related changes are most visible sign of aging process. Evidence of increasing age includes wrinkles and sagging skin. With age outer skin layer thins, even though the number of cell layers remains unchanged. Changes in the connective tissue reduces the skins strength and elasticity This is known as elastosis. Sebaceous glands produce less oil as increased with age ${ }^{8}$.

\section{Concept of Abhyanga}

\section{Etymology of Abhyanga}

According to Amarkosha the word Abhyanga derived when "Abhi" upasarga is added to Anga which means to induce specific in special movement. In Ayurveda Abhyanga means applying oil followed by light massage in specific direction. There is various terminology of Abhyanga ccording to part of body for example then Sneha is applied on head it is called as Shirobhyanga, when Sneha applied on foot it called as Padabhyanga.

\section{Indication of Abhyanga}

\section{Abhyanga in Dincharya}

Abhyanga is indicated as part of Dincharya to promote the health. Regular practice of Abhyanga acts as Jarahar, Shramahar, Vatahar. It also beneficial for Netra especially Padabhyanga, acts as Prushtikara, Nidrakara.

\section{Abhyanga in Rutucharya}

Abhyanga is to be advised in Hemant ritu to protect the body from biting cold of Hemant ritu.
Abhyanga in Vegavidharniyajanya vyadhi 
Abhyanga is advised for the treatment of symptoms caused due to holding or suppressing the urges of Adhovata, Shakrit, Mutra, Kshut, Nidra, Shramashwasa, Vamathu, Shukra etc.

\section{Abhyanga in different diseases}

Sneha used for Pana ,Nasya, Anuvasana, and Abhyanga. Abhyanga is mainly indicated in Vata predominant states of diseases. Abhyanga followed by Swedana bring down the disfigured and painful body parts which occur due to aggravation Vata.

\section{Absorption of Sneha}

\section{Effect of Abhyanga on various Dhatu}

The commentator of Sushruta, Dalhana has describes the effect of Abhyanga is described according to its duration.

When Abhyanga done for 300 Matra Sneha reaches to Romkupa. Here 1 Matra is equal to $19 / 60$ seconds, so 300 Matra means 95 seconds. Similarly in 400 Matra (133 second) Sneha reaches up to Twacha, in 500 Matra (160 second) it reaches up to Raktadhatu, in 600 Matra (190 second ) it reaches up to Mamsa Dhatu, in 700 Matra (228 second) it reaches up to Meda Dhatu, in 800 Matra (240 second) it reaches up to Asthi Dhatu and it reaches up to Majja Dhatu when Abhyanga is performed up to 900 Matra (280 seconds).

\section{Absorption of oil through Skin}

The skin is relatively permeable to fat soluble substances. Essential oil molecules are so minute that when they are able to pass through stratum corneum (outer layer of the epidermis). From here the oil molecules passes through dermis, into the capillaries and into bloodstream.
Absorption also occurs through hair follicle and sweat ducts ${ }^{9}$. In Abhyanga the Snehadravya has applied over the skin and gently massaged with light pressure, due to this penetration of Sneha is forced into the hair follicle and gland is increased. In this way absorption oil through skin layer occurs.

\section{Mode of action of Abhyanga}

Commentator of Sushrut Samhita, Dalhana has described the absorption of Sneha used in Abhyanga reaches up to the different Dhatus when it applied for the sufficient time. Thus, the Dravya used in Abhyanga get absorbed through skin and it reaches to the particular Dhatu and it subside the diseases of particular Dhatu.

Acharya Charaka stated that Vayu is dominates in Sparshanendriya which is ocated in Twacha, further he also describes the important link between Mana, and all senses ${ }^{10}$.

Indriya are in close contact of mind, so when Indriyas remain healthy then mind automatically remains healthy, thus Abhyanga keep body and mind healthy.

The colour and luster of Skin is mainly due to the Bhrajaka pitta which is located in skin. Acharya Charaka has stated that the normal and abnormal temperature and colour is due to Bhrajaka pitta. The variation in skin is due to Bhrajak pitta. Arundatta has describes Bhrajaka Pitta and its functions like Deepana and Pachana. Thus, when Sneha applied over skin it got digested by the Bhrajaka pitta. Acording to Acharya Indu, Abhyanga diminished the hardness and roughness of skin, so from this point of view we can say 
that Abhyanga help in improving the quality of skin.

Padabhyanga, helps in improve vision ${ }^{11}$ .As there is a link between Pada and Netra. Both are consider as two poles of body $^{12}$. The medicine administrated from Pada reaches up to Netra. Hence, we can say that Padabhyanga can beneficial for the Netra. Also, Padabhyanga relived Kharata, Suptata, Srama and Suptata of Pada. The Bhavaprakasha have quoted that disease do not go near one who massage his feet before sleeping just as snake do not approach eagles ${ }^{13}$.

\section{Mode of action of Abhyanga on the basis of properties of Snehadravya}

The Snehadravyas contains the following Gunas and their properties are mentioned below

Snigdha Guna responsible for the action Snehana, Kledana and Vishyandana cellular level of body. The properties of Snigdhguna are opposite that of Vata, so it acts as Vatahar and Kaphakar. Guru Guna having the property like Vatahara and Kaphakara, due to this it alleviates the morbid Vata, increases the decreases Kapha. Sheeta Guna prevents fainting and decreases the perspiration. It helps in stabilizing the muscles and organs. Mridu Guna have opposite properties that of Kathin Guna. By this property of Abhynaga it reduces the stiffness. Drava Guna liquefies the Doshas and mobilizes the Doshas by increasing their flowing capacity. Picchila Guna gives longevity, increases body strength. Sara Guna mobilizes the Doshas and Malas i.e. mobilizes waste product by this property. Because of Manda Guna the drug diffuse slowly by this property and it remain in the contact of Dosha, Dhatus and Malas for longer time. Sukshma Guna helps the drug to enter in the fine channels.

\section{Mode of action of Abhyanga according to ModernView}

The internal fluids of the skin are subjected to movement in the massage because of osmotic pressure. Here massage is causing mechanical hydrostatic pressure in the extra cellular compartment. A forceful expulsion from peripheral vessel cause splanchenic pooling of the body. Massage helps fluid enter into viscera, tissues and dilute the accumulated toxins.

After the completion of procedure; when it refills the peripheral vessels, the diluted toxins are brought into general circulation and during course; they are expelled out ia elimination procedures.

Abhyanga acts on skin (Twacha), which is the seat for the both Vata and lasika. In this way; the lymphatic drainage will be the prime effect of Abhyanga. Lymph exhibits large amount of amino acid tryptophan.

Hypothetically, after massage; amino acids like tryptophan increase in blood. It cause a parallel increase in the neuron transmitter serotonin; which is made from tryptophan at motor ends plates.

The piezoelectricity is derived from pressure. While utilizing a medium of unctuous substance to reduce the friction a good amount of rhythm is used and creates magnetic field and electricity in the body. By charging the conductivity of nerves will be increased which may go up 100 metres per second. Electricity is 
discharged in nerve fibre at regular intervals and moves in circular pattern.

Interruption to momentum is resulting into the state of disease, which may be pacified by doing massage with specific pressure. Acetylcoline acts as transmitter at motor end in the presence of calcium ion and facilitates synaptic action potential.

The nerve fibres have a mylenated sheet in which lipids are the chief ingredients. $\mathrm{Na}$ and $\mathrm{K}$ ions are responsible for the repolarisation in the nerve fibre. This action with the association of melatonin; a by- product of serotonin and a neuro chemical is causing pleasant and calming effect by the massage. With the concentrated from of the drug; the absorption rate increases. Percutaneous absorption is observed in the inflammatory condition due to the presence substances ${ }^{14}$.

\section{Health benefits of Massage}

The following are the key effect of Massage

\section{- Reduce Muscle Tension}

Massage affects the muscles in the body. It affects the muscles and other soft tissue in the body. Massage loosens contracted, shortened, hardened muscles. It may stimulate flaccid muscles. Chronic muscle tension is causing in reduction of the circulation of the body and movement of lymph area.

\section{- Improves Blood Circulation}

The oxygen capacity of the blood can increase $10-15 \%$ by the procedure of massage. With the help of direct or indirect stimulating nerves that supply internal organs, blood vessels of these organ dilated and allow more blood supply to them.

\section{- Induces better Lymph Movement}

Lymph is milky white fluid that helps in draining of impurities and waste away from the tissue cells. A component of these waste is called as toxins which are the by-product of metabolism. That's why; it is vital to our health. Muscular contraction is having a pumping effect that moves lymph. Massage helps to move lymph.

- Results in Increased Mobility and Range of Motion of Joints

Massage provides a gentle stretching action to both the muscles and connective tissues which supports the muscles and many other parts of the body and which help to keep these tissues elastic.

- Stimulation or Soothes Nervous system

Massage enhances the skin condition by improving the function the function of the sebaceous and sweat glands, which keep the skin lubricated, clean.

- Results in Better Digestion and Intestinal Function

Massage procedure increases the body's secretions and excretion. It also increases the production of gastric juices, saliva and urine. There is an increased excretion of nitrogen, inorganic phosphorous and salt also. Thus, results in increasing metabolic rate $^{15}$.

\section{DISCUSSION}

In Ayurvedic classical text it was stated that Vatadosha is dominant in 
Vriddhavastha, Snehadravya used for Abhynga has opposite properties that of Vata, so it alleviates the Vata . According to Sharangadhara there is Hrasa of Chhavi means complexion from $3^{\text {rd }}$ decade of life. In Abhyanga procedure Sneha dravya is applied over skin which is seat of Bhrajaka pitta. According to Acharya Charaka Bhrajaka Pitta is responsible for the complexion of skin. So we can say that Abhyanga helpful in the inhancing the complexion of skin. In the $5^{\text {th }}$ decade of life Twacha means skin losses it elasticity and wrinkles appears, also the sebaceous glands and sweat gland produces less oil due to this skin became Rooksha. Skin related changes are noticeable in elderly person from $5^{\text {th }}$ decade. According to Charaka Valli (Wrinkles) are due to Rasakshya and Sushruta says that it is because of Raktakshaya, further he also stated that there is a Kshaya Rasaraktadi Dhaus in Vriddhavasthd According to Dalhana, while describing the time duration of Abhynga, the Snehadravya nourishes the Dhatus. Hence, Abhyanga slowers the aging process. Abhyanga improves the function of Sebaceous gland and sweat glands, which keep the skin lubricated, so that there is Shaman of Rooksh Guna of Vata. In $9^{\text {th }}$ decade of life there will be Hrasa of Manaha. Acharya Charaka stated that Vayu is dominates in Sparshanendriya which is located in Twacha, further he also describes the important link between Mana, and all senses. So Abhyanga acts on Manovahastrotas, and produces sound sleep. During Abhyanga amino acids like tryptophan increase in blood. It causes a parallel increase in the neuron transmitter serotonin.
Low Serotonin levels are believed to be linked with depression, insomnia; when levels of serotonin are brought normal, sleep falls into place ${ }^{16}$.

\section{CONCLUSION}

Abhyanga is one of the procedures to be practiced in Dincharya. The advantages and beneficial in the management of Jara. Abhyanga is easy procedure, economic and effective. It increases the blood and lymph flow and in this way nourishes skin and local tissue. Abhyanga improves the complexion of skin, it also nourishes the Rasaraktadi Dhatu, improves the functioning of sebaceous gland and sweat gland, prevent from the skin related changes occurs in old age. Increased in the level of neuron transmitter serotonin produces sound sleep in elderly persons. So we can say that Abhyanga in daily beneficial in preventing ageing related changes.

\section{REFERENCES}

1) Kaviraj Ambikadattashastri, Chaukhambha Sanskrit Sansthana, Edition, Reprint 2013, Sushruta Samhita (Purvardha), Sutrasthana chapter no.1, Shloka No. 33, Page no.10

2) Dr. Brahmanand Tripathi, Chaukhamba Sanskrit Pratisthana, Reprint 2015, Ashtanga Hridayam, Sutrasthana chapter no.1, Slok no.8, Page no.5

3) Dr. Brahmanand Tripathi, Chaukhamba Sanskrit Pratisthana, Reprint 2015, Ashtanga Hridayam, Sutrasthana chapter no.2, Slok no.8, Page no. 29

4) Acharya Viddhadhara Shukl, Pro. Ravidatta Tripathi, Chaukhamba 
Sanskrit Pratisthana, Charaka Samhita, Vimansthana chapter no.8, Slok No122, Page no.654

5) Kaviraj Ambikadattashastri, Chaukhambha Sanskrit Sansthana, Edition, Reprint 2013, Sushruta Samhita (Purvardha), Sutrasthana chapter no35, Shloka No. 34, Page no. 173

6) Dr. Brahmanand Tripathi, Chaukhamba Surbharati Prakashan, Reprint 2012, Sharangadhar Samhita, Purvakhanda Chapter no. 6, Shlok no.62. Page no.86

7) Kaviraj Ambikadattashastri, Chaukhambha Sanskrit Sansthana, Edition, Reprint 2013, Sushruta Samhita (Purvardha), Sutrasthana chapter no.35, Shloka No. 36, Page no. 174

8) Aging changes in skin.MedlinePlus Medical https:/medlineplus.gov.

9) Leah Morghan, Clinical Aromatherapist, How essential oil Enters The Body,https://healingscents.net/blog 10) Pandit Kashinath Shastri, Gangasahay Pandey, Chaukhamba Sanskrit Sansthana, Charaka
Samhita, Sutrasthana chapter no.8, Slok No10,12 Page no.120

11) Acharya Viddhadhara Shukl, Pro. Ravidatta Tripathi, Chaukhamba Sanskrit Pratisthana, Charaka Samhita, Sutrasthana chapter no.5, Slok No91, Page no.101

12) Dr. Brahmanand Tripathi, Chaukhamba Sanskrit Pratisthana, Reprint 2015, Astanga Hridayam, Uttarsthana chapter no.16, Slok no.66, Page no.998

13) Bhavamishra. Bhavaprakasha with viddyodinitik, Brahmashankara Mishra, Chaukhamba Sanskrit series varansi 2003 purvakhanda 5/73-74 p 116.

14) Vaidya Vasant Patil, Principles and Practices in Panchakrm, $4^{\text {th }}$ Edition,2012, page no.137,178

15) Jennifer Jacoba,MD, MPH, Consultant Editor, Encyclopedia of Alternative Medicine, Retrieved from:http://www.lushotoexecutivel odge.co.tz/images/uploads/surhud_ heaith_pdf.pdf

16) Vashadez shV.Georgion Med News 2007, Insomnia, Serotonin, Depression http://www.ncbi.nlm.nih.govPubm ed

Cite article:

ROLE OF ABHYANGA IN JARA - A REVIEW

Rashmi G. Dike, Sumit R. Patil

Ayurlog: National Journal of Research in Ayurved Science- 2018; (6)(6):1-7 